\title{
Pollen Analysis of the Honeys Samples Produced in the Three Phyto-geographical Zones of Benin
}

François Ezin Azonwade, Msc.

Laboratory of Biology and Molecular Typing in Microbiology, Faculty of

Sciences and Technology/University of Abomey-Calavi, Benin

\section{Armand Paraïso, PhD}

Laboratory of Plant Protection, Bees Pathology and Parasitology, Faculty of

Agronomy/University of Parakou, Benin

Monique G. Tossou, PhD

Laboratory of Botany and Plant Ecology, Faculty of Sciences and

Technology/University of Abomey-Calavi, Benin

\author{
Haziz Sina, PhD \\ Aude Eminsede Kelomey, PhD \\ Kamirou Chabi-Sika, PhD \\ Lamine Baba-Moussa, PhD
}

Laboratory of Biology and Molecular Typing in Microbiology, Faculty of

Sciences and Technology/University of Abomey-Calavi, Benin

doi: 10.19044/esj.2017.v13n18p528 URL:http://dx.doi.org/10.19044/esj.2017.v13n18p528

\begin{abstract}
The aim of this work was the melissopalynologycal analysis of the honey samples collected both during the dry and rainy seasons of the three phyto-geographical zones of Benin. The analysis was performed by conventional methods on 60 honeys samples. The total of 138 taxa have been identified at family level (31), genus level (20) and to the level species (87). The number of pollens counted varies according to the phyto-geographical zones. Thus, 17091 pollens have been counted in the samples of the Sudanian zone; 13884 in those of the Sudano-Guinean zone and 7960 pollens in those of the Guinean zone. The pollen content of the honey samples reflects the plant species of the three phyto-geographical zones. The most dominant plant taxa were Combretaceaes (26.01\%) and Parkia biglobosa (10.67\%) in Sudanian zone, Combretaceae (29.52\%) in SudanoGuinean zone. In the Guinean zone, the dominant taxa were Zea mays $(18.35 \%)$ and Terminalia (15.34\%). The specific richness varies from 6 to 43 in the Sudanian zone, from 7 to 34 in the Sudano-Guinean zone and from 1
\end{abstract}


to 28 taxa in the Guinean zone. None of the density of the dominant pollens reached $45 \%$, thus all the analyzed honeys are polyfloral.

Keywords: Honeys - pollens - phytogeographical zones - Vegetation - Benin

\section{Introduction}

Beekeeping is an old practice of the agricultural production system in the world and particularly in sub-Saharan Africa (Tchoumboue et al., 2001). Among these products of the hive, the honey constituted during millennia in west, the only abundant source of sugary matters of which one could arrange (Alvarez-Suarez et al., 2013). The honey is one of the oldest agents of the alleviation and is defined as the natural sugary substance produced by the bee Apis mellifera var. adansonii, from the nectar of plants or secretions coming from living parts of the plants or excretions let on these by bugs suckers, than them gather nectar, transform while combining them with clean specific matters, deposit, dehydrate, store and let ripen in the rays of the hive (Feás et al., 2010). This natural product is also valuable as a marketable commodity, both in domestic and international markets and plays an important role in some cultural traditions (Canini et al., 2005). It thus constitutes a significant potential source of income for the rural population while at the same time contributing to the improvement of human nutrition (Nija, 1998).

The composition of this natural product makes it a source rich in available sugars, organic acids, amino acids and a source of biologically active compounds (Chefrour et al., 2009). The composition of honey varies according to the source of flowers used by bees, the harvest period and the geo-climatic conditions of the regions concerned (Yédomonhan et al., 2009). So, it is intimately linked to a type of plant called "honey plants" despite being a product actually produced by the bee following concentration and biochemical transformation (Darrigol, 1996). Honey plants are plant species from which the bee harvests substances, including nectar, pollen and resin for food and to produce various products including honey (Dongock et al., 2004). Many studies have focused on the inventory of these plants in subSaharan Africa (Agwu and Akambi, 1985, Agwu et al., 1989, LobreauCallen and Damblon, 1994, Yédomonhan et al., 2009, Tossou et al., 2011). However, those knowledge can also be made through pollen analyzes, that is to say the identification of the pollens contained in the samples of honey.

This study, which is part of the characterization and study of the biological activity of the samples of honeys harvested in the three phytogeographical zones of Benin during the dry and rainy seasons, focused on pollen analysis. Its objective is to demonstrate the relationships between the taxa present in the honey samples and the phytogeographical zones. 


\section{Material and methods \\ Study area}

This study was carried out in the three phytogeographical zones (Sudanian, Sudano-guinean and Guinean) of Benin previously described by Akoègninou, (2004). The differentes zones of survey, Sudanian, SudanoGuinean and Guinean are situated respectively at the North, to the Center and to the South of Benin (Figure 1).

\section{Collection of Honey Sample}

A total of 60 honey samples were used for this study. They were collected in ten different localities of each phytogeographic zone during the dry and rainy seasons. In each of the phytogeographic zones, 10 samples per season were collected from beekeepers. In total, for each phytogeographic zone, 20 samples of honey were collected (Table 1). The samples were stored in sterile, hermetically sealed glass vials, labeled ( $\mathrm{S}=$ dry season and $\mathrm{P}=$ rainy season), dated, and kept at room temperature $\left(25-30^{\circ} \mathrm{C}\right)$, until further analysis.

The harvest periods of the honey samples were from November to April (dry seasons) and from June to September (rainy seasons) in the Sudanian and Sudano-guinean zones. In the Guinean zone, the dry season sampling ranged from November to March and from mid-July to midSeptember, and the rainy season from April to mid-July and from midSeptember to October (Sinsin et al., 2004).

\section{Pollen analysis and honeys treatment}

For each sample, $10 \mathrm{~g}$ of honey were taken and then diluted in $10 \mathrm{ml}$ of distilled water and then treated with acetolysis by the Erdtmann (1960, 1969) method. The pollen analysis of the samples was carried out using a trilocular photon microscope (Olympus®). The magnifications (x200) and (x400) were used for pollen identification and counting. The determinations were made by comparison with the reference blade collections of the Palynology Unit of the Laboratory of Botany and Plant Ecology of the University of Abomey-Calavi in Benin and the appropriate pollen literature illustrations (Ybert, 1979; Sowunmi, 1995 and Tossou, 2002). The botanical identification of pollen was carried out either at the family level or at the genus and / or species level on the basis of the nomenclature of Akoègninou et al. (2006).

The pollen diversity was expressed from the specific richness according to the method of Yédomonhan (2009). The author distinguishes three classes of specific riches: the class of honey that is very poor in species (less than 5 taxa): that of the relatively rich honey (between 5 and 15 taxa) and that of the honey rich in species (more than 15 taxa). 
The relative frequency and relative density of each identified taxon were calculated for each sample. The relative frequency or frequency of distribution of pollen represents the belonging of the identified taxa to the three phytogeographical zones (Yédomonhan, 2009). The percentage quotient of the number of honey samples containing the taxon on the total number of honey samples analyzed. Thus, are distinguished according to the recommendations of Louveaux et al. (1978) and Feller-Desmaly and Parent (1989).

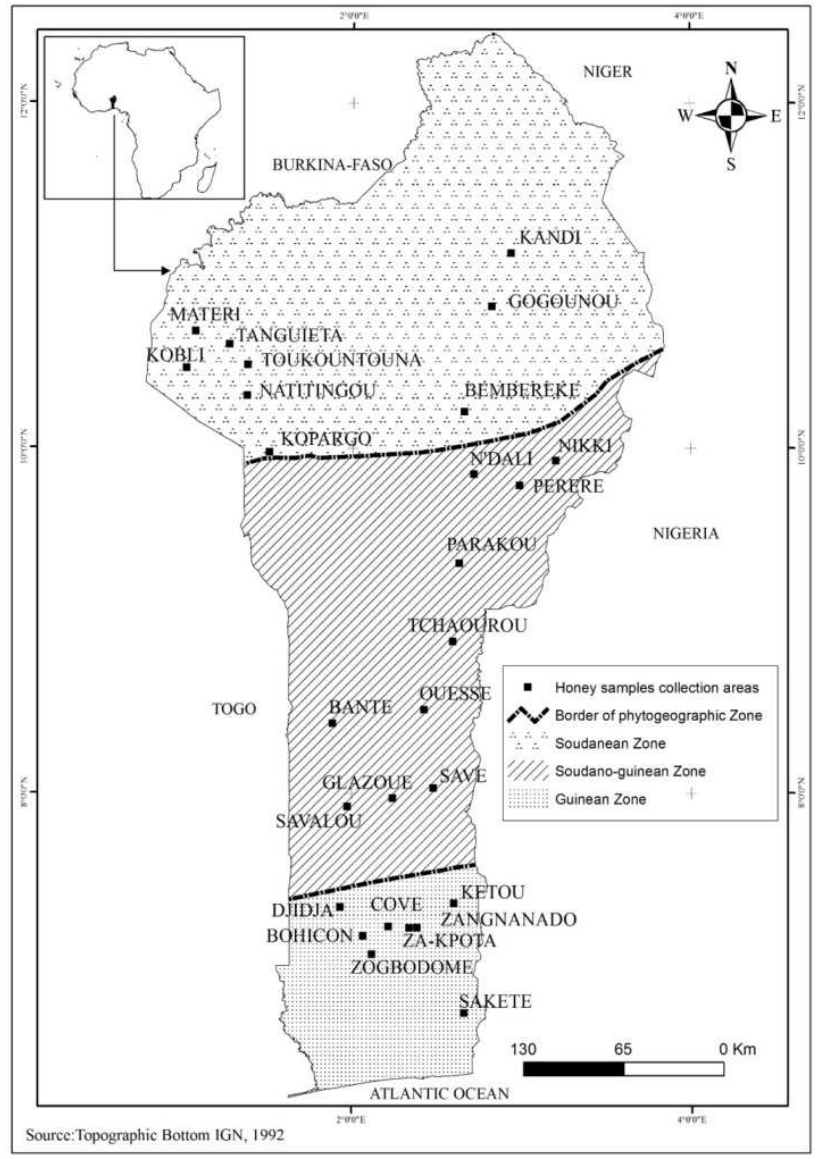

Figure 1. Map of the phyto-geographical zones of Benin with the samples collection areas 
Table 1: Zones and localities of collection of the honey samples according to the seasons

\begin{tabular}{|c|c|c|c|}
\hline $\begin{array}{c}\text { Zones } \\
\text { (number of } \\
\text { samples) }\end{array}$ & $\begin{array}{l}\text { Coding of the } \\
\text { samples of the dry } \\
\text { season } \\
(n=10)\end{array}$ & $\begin{array}{l}\text { Coding of the } \\
\text { samples of the } \\
\text { rainy season } \\
(n=10)\end{array}$ & $\begin{array}{c}\text { Localities } \\
(\mathrm{n}=10 \text { by zone })\end{array}$ \\
\hline \multirow{10}{*}{ 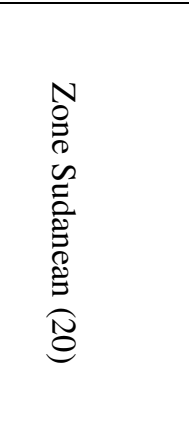 } & $\mathrm{SoS}_{1}$ & $\mathrm{SoP}_{1}$ & Bembèrèkè \\
\hline & $\mathrm{SoS}_{2}$ & $\mathrm{SoP}_{2}$ & Cobly \\
\hline & $\mathrm{SoS}_{3}$ & $\mathrm{SoP}_{3}$ & Copargo \\
\hline & $\mathrm{SoS}_{4}$ & $\mathrm{SoP}_{4}$ & Bagou \\
\hline & $\mathrm{SoS}_{5}$ & $\mathrm{SoP}_{5}$ & Kandi \\
\hline & $\mathrm{SoS}_{6}$ & $\mathrm{SoP}_{6}$ & Matéri \\
\hline & $\mathrm{SoS}_{7}$ & $\mathrm{SoP}_{7}$ & Natitingou/Korimbéré \\
\hline & $\mathrm{SoS}_{8}$ & $\mathrm{SoP}_{8}$ & Natitingou/centre \\
\hline & $\mathrm{SoS}_{9}$ & $\mathrm{SoP}_{9}$ & Tanguiéta \\
\hline & SoS $_{10}$ & $\mathrm{SoP}_{10}$ & Toucountouna \\
\hline \multirow{8}{*}{ 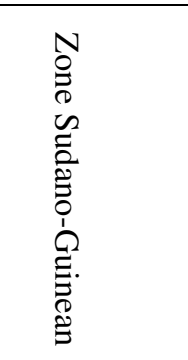 } & $\mathrm{SgS}_{1}$ & $\mathrm{SgP}_{1}$ & Bantè \\
\hline & $\mathrm{SgS}_{2}$ & $\mathrm{SgP}_{2}$ & Glazoué \\
\hline & $\mathrm{SgS}_{3}$ & $\mathrm{SgP}_{3}$ & N'dali \\
\hline & $\mathrm{SgS}_{4}$ & $\mathrm{SgP}_{4}$ & Nikki \\
\hline & $\mathrm{SgS}_{5}$ & $\mathrm{SgP}_{5}$ & Ouessè \\
\hline & $\mathrm{SgS}_{6}$ & $\mathrm{SgP}_{6}$ & Parakou \\
\hline & $\mathrm{SgS}_{7}$ & $\mathrm{SgP}_{7}$ & Pérèrè \\
\hline & $\mathrm{SgS}_{8}$ & $\mathrm{SgP}_{8}$ & Savalou \\
\hline \multirow{2}{*}{ 응 } & $\mathrm{SgS}_{9}$ & $\mathrm{SgP}_{9}$ & Savè \\
\hline & $\mathrm{SgS}_{10}$ & $\mathrm{SgP}_{10}$ & Tchaourou \\
\hline \multirow{10}{*}{ 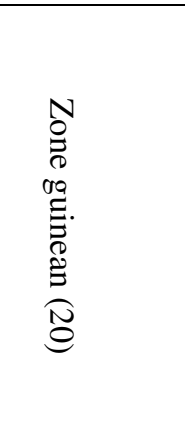 } & $\mathrm{GuS}_{1}$ & $\mathrm{GuP}_{1}$ & Bohicon/centre \\
\hline & $\mathrm{GuS}_{2}$ & $\mathrm{GuP}_{2}$ & Bohicon/Cana \\
\hline & $\mathrm{GuS}_{3}$ & $\mathrm{GuP}_{3}$ & Covè \\
\hline & $\mathrm{GuS}_{4}$ & $\mathrm{GuP}_{4}$ & Djidja \\
\hline & $\mathrm{GuS}_{5}$ & $\mathrm{GuP}_{5}$ & Ketou \\
\hline & $\mathrm{GuS}_{6}$ & $\mathrm{GuP}_{6}$ & Saketé \\
\hline & $\mathrm{GuS}_{7}$ & $\mathrm{GuP}_{7}$ & Zakpota \\
\hline & $\mathrm{GuS}_{8}$ & $\mathrm{GuP}_{8}$ & Zangnanado \\
\hline & $\mathrm{GuS}_{9}$ & $\mathrm{GuP}_{9}$ & Zogbodomey/Dovogon \\
\hline & $\mathrm{GuS}_{10}$ & $\mathrm{GuP}_{10}$ & Zogbodomey/Mongon \\
\hline
\end{tabular}

i)

ii)

iii)

iv) very frequent pollens $(>50 \%)$,

frequent pollens (20 to $50 \%$ ),

infrequent pollens (10 to $20 \%$ ), and

rare pollutants $(<10 \%)$.

The relative density (Dr) is expressed as the percentage quotient of the absolute density of a pollen type on the sum of the absolute densities of all pollen types in the sample. It is calculated for each sample of honey that 
has at least 1200 grains of pollen. The evaluation is made according to the method of Feller-Desmaly and Parent (1989) which distinguish:

i) Dominant pollens (Dr $>45 \%)$,

ii) accompaniment of pollens $(16 \leq \mathrm{Dr} \leq 45 \%)$,

iii) important isolated pollens $(4 \leq \mathrm{Dr} \leq 16 \%)$, and

iv) isolated Pollens ( Dr $\leq 3 \%)$

\section{Statistical analyses}

The raw pollen data was processed using the Microsoft Office Excel 2010 spreadsheet. The hierarchical numerical classification was used to determine groups of similar pollen composition with the FactoMineR package in software $\mathrm{R}$ 3.2.3. Then, the indicator species of the different groups of honeys obtained were determined using the frequency of occurrence of the pollens of the species in the honey groups. The indicator species of the honey groups are those with the highest pollen frequencies.

\section{Results}

\section{Pollen spectrum of analyzed honeys samples}

The pollen analysis of the 60 honey samples identified 138 taxa belonging to 31 families, 20 genera and 87 species. The pollen sum varies from 58 to 2732 pollen grains per sample. The largest number of pollen was counted in the samples of the Sudanian zone (17091 pollens), followed by samples from the Sudano-Guinean zone (13884) and then samples from the Guinean zone (7960 pollens). Pollen diversity varies from an area to another. So, the largest diversity was recorded in the Sudanian zone (6-43 taxa / sample), followed by the Sudano-guinean zone (7-34 taxa / sample) and the Guinean zone with 7-28 taxa per sample (Table 2).

The total taxonomic richness is also higher in the Sudanian zone (118 taxa) than in the other two zones with 112 taxa in the Sudano-guinean zone and 89 taxa in the Guinean zone.

Table 2: Pollen spectrum of analyzed honeys samples

\begin{tabular}{cccc}
\hline & Sudanian zone & $\begin{array}{c}\text { Sudano-guinean } \\
\text { zone }\end{array}$ & Guinean zone \\
\hline Pollen nombers & 17091 & 13884 & 7960 \\
Pollen diversity & 6 à 43 & 7 à 34 & 7 à 28 \\
Pollen taxons & 118 & 112 & 89 \\
\hline
\end{tabular}

\section{Pollen diversity}

We can distinguish globally the existence of two classes within the samples of honeys analyzed according to the method of Yédomonhan, (2009). These are the class of relatively rich honey (between 5 and 15 taxa) and that of honey rich in species (more than 15 taxa). These two classes are found in the samples of the three phytogeograhic zones. No sample of honey 
from the three phytogeographic zones belongs to the very poor pollen honey class (Table 3 ).

Table 3: Species richness of honey samples from the three phytogeographical zones

\begin{tabular}{cccc}
\multirow{2}{*}{$\begin{array}{c}\text { Specific } \\
\text { richness }\end{array}$} & \multicolumn{2}{c}{ Number of honey samples per phytogeographic zone } \\
\cline { 2 - 4 } & Guinean zone & Sudanian Zone & $\begin{array}{c}\text { Sudano-guinean } \\
\text { Zone }\end{array}$ \\
\hline$[5 ; 15]$ taxa & 7 & 4 & 3 \\
\hline$[15 ;+]$ taxa & 13 & 16 & 17 \\
\hline
\end{tabular}

\section{Frequency of the grains of pollens}

From the pollen analysis of the honey samples, it appears that among the 138 taxa identified, $54(38.02 \%)$ are present in the three phytogeographical zones; $43(30.28 \%)$ in two phytogeograhic zones and 19 species (13.38\%), are found in one phytogeographical zones (Table 4). Of the number of taxa identified only 31 are taxa at the family level, 20 taxa at the genus level and 87 taxa at the species level. Of these 31 families, $48.38 \%$ (15) are common to the three phytogeographical zones, $4(12.90 \%)$ families belong to two phytogeographic zones and 7 (22.58\%) families are found in a single phytogeographical zone.

Table 4: Frequency of the pollens according to the phytogéographical zones

\begin{tabular}{|c|c|c|c|}
\hline List of the Species & $\begin{array}{c}\text { Sudanian } \\
\text { zone }\end{array}$ & Sudano-guinean zone & $\begin{array}{c}\text { Guinean } \\
\text { zone }\end{array}$ \\
\hline $\begin{array}{c}\text { Acacia sp (Leguminosae- } \\
\text { Mimosoideae) }\end{array}$ & $*$ & $*$ & $*$ \\
\hline Acalypha crenata (Euphorbiaceae) & & $*$ & $*$ \\
\hline Acanthaceae & $*$ & $*$ & $*$ \\
\hline Adansonia digitata (Bombacaceae) & $*$ & $*$ & \\
\hline Ageratum conyzoides (Asteraceae) & & $*$ & $*$ \\
\hline Leguminosae-Mimosoideae & $*$ & $*$ & $*$ \\
\hline $\begin{array}{c}\text { Alchornea cordifolia } \\
\text { (Euphorbiaceae) }\end{array}$ & $*$ & $*$ & $*$ \\
\hline $\begin{array}{c}\text { Allophyllus africanus } \\
\text { (Sapindaceae) }\end{array}$ & & $*$ & $*$ \\
\hline Amaranthaceae & $*$ & $*$ & \\
\hline Anarcadiaceae & $*$ & $*$ & $*$ \\
\hline $\begin{array}{c}\text { Anacardium occidentale } \\
\text { (Anarcadiaceae) }\end{array}$ & $*$ & $*$ & $*$ \\
\hline $\begin{array}{c}\text { Aneilema beninense } \\
\text { (Commelinaceae) }\end{array}$ & $*$ & & \\
\hline Annona senegalensis (Annonaceae) & $*$ & $*$ & $*$ \\
\hline $\begin{array}{c}\text { Anogeissus leiocarpa } \\
\text { (Combretaceae) }\end{array}$ & $*$ & $*$ & $*$ \\
\hline Antidesma-type (Euphorbiaceae) & $*$ & $*$ & \\
\hline
\end{tabular}




\begin{tabular}{|c|c|c|c|}
\hline List of the Species & $\begin{array}{l}\text { Sudanian } \\
\text { zone }\end{array}$ & Sudano-guinean zone & $\begin{array}{c}\text { Guinean } \\
\text { zone }\end{array}$ \\
\hline $\begin{array}{c}\text { Antrocaryon micrater } \\
\text { (Anarcadiaceae) }\end{array}$ & $*$ & $*$ & \\
\hline Apocynaceae & $*$ & $*$ & $*$ \\
\hline Arecaceae & $*$ & & \\
\hline Aspilia africana (Asteraceae) & & $*$ & $*$ \\
\hline Aspilia bussei (Asteraceae) & $*$ & $*$ & \\
\hline Asteraceae & $*$ & $*$ & $*$ \\
\hline Azadirachta indica (Meliaceae) & $*$ & & \\
\hline $\begin{array}{c}\text { Baphia pubescens (Leguminosae- } \\
\text { papilionoideae) }\end{array}$ & $*$ & & \\
\hline $\begin{array}{c}\text { Berlinia grandiflora } \\
\text { (Leguminosae-caesalpinoideae) }\end{array}$ & $*$ & $*$ & $*$ \\
\hline Bombax costatum (Bombacaceae) & $*$ & $*$ & $*$ \\
\hline Borassus aethiopium (Arecaceae) & $*$ & $*$ & $*$ \\
\hline $\begin{array}{c}\text { Bridelia ferruginea } \\
\text { (Euphorbiaceae) }\end{array}$ & $*$ & $*$ & $*$ \\
\hline Canthium-type (Rubiaceae) & $*$ & & \\
\hline Leguminosae-caesalpinoideae & $*$ & & \\
\hline $\begin{array}{c}\text { Cassia hirsuta (Leguminosae- } \\
\text { caesalpinoideae) }\end{array}$ & & $*$ & $*$ \\
\hline $\begin{array}{c}\text { Cassia mimosoides (Leguminosae- } \\
\text { caesalpinoideae) }\end{array}$ & $*$ & $*$ & $*$ \\
\hline Ceiba pentandra (Bombacaceae) & $*$ & $*$ & $*$ \\
\hline Chassalia kolly (Rubiaceae) & $*$ & $*$ & $*$ \\
\hline Cissus polpunea (Vitaceae) & $*$ & $*$ & $*$ \\
\hline $\begin{array}{c}\text { Clerodendrum polycephalum } \\
\text { (Verbenaceae) }\end{array}$ & $*$ & $*$ & \\
\hline Cnestis ferruginea (Connaraceae) & $*$ & & $*$ \\
\hline $\begin{array}{c}\text { Cocchlospermum planchonii } \\
\text { (Cochlospermaceae) }\end{array}$ & $*$ & $*$ & $*$ \\
\hline Combretaceae & $*$ & $*$ & $*$ \\
\hline Combretum sp (Combretaceae) & $*$ & $*$ & $*$ \\
\hline $\begin{array}{c}\text { Combretun collinum } \\
\text { (Combretaceae })\end{array}$ & $*$ & $*$ & $*$ \\
\hline Commelina-type (Commelinaceae) & $*$ & $*$ & $*$ \\
\hline Commelinaceae & $*$ & & \\
\hline Convolvulaceae & $*$ & $*$ & $*$ \\
\hline Corchorus olitorius (Tiliaceae) & $*$ & $*$ & $*$ \\
\hline Cordia sinensis (Boraginaceae) & $*$ & $*$ & $*$ \\
\hline
\end{tabular}




\begin{tabular}{|c|c|c|c|}
\hline List of the Species & $\begin{array}{l}\text { Sudanian } \\
\text { zone }\end{array}$ & Sudano-guinean zone & $\begin{array}{c}\text { Guinean } \\
\text { zone }\end{array}$ \\
\hline $\begin{array}{c}\text { Crossopterix ferrugenea } \\
\text { (Rubiaceae) }\end{array}$ & $*$ & $*$ & $*$ \\
\hline Curcubitaceae & $*$ & & \\
\hline Cyanotis lanata (Commelinaceae) & $*$ & & $*$ \\
\hline Cyperaceae & $*$ & $*$ & $*$ \\
\hline $\begin{array}{c}\text { Daniella oliveri (Leguminosae- } \\
\text { caesalpinoideae) }\end{array}$ & $*$ & $*$ & $*$ \\
\hline $\begin{array}{c}\text { Detarium microcapum } \\
\text { (Leguminosae-caesalpinoideae) }\end{array}$ & $*$ & $*$ & $*$ \\
\hline $\begin{array}{c}\text { Dichrostachys cinerea } \\
\text { (Leguminosae-Mimosoideae) }\end{array}$ & $*$ & $*$ & $*$ \\
\hline $\begin{array}{c}\text { Diospyros mespiliformis } \\
\text { (Ebenaceae) }\end{array}$ & $*$ & $*$ & $*$ \\
\hline Ebenaceae & $*$ & & \\
\hline Elaeis guineensis (Arecaceae) & $*$ & $*$ & $*$ \\
\hline $\begin{array}{c}\text { Entada-type (Leguminosae- } \\
\text { Mimosoideae) }\end{array}$ & & $*$ & $*$ \\
\hline $\begin{array}{c}\text { Erythrina senegalensis } \\
\text { (Leguminosae-Papilionoideae) }\end{array}$ & & $*$ & $*$ \\
\hline $\begin{array}{c}\text { Erythroxylum emarginatum } \\
\text { (Ebenaceae) }\end{array}$ & $*$ & & \\
\hline Euphorbia sp (Euphorbiaceae) & $*$ & $*$ & $*$ \\
\hline Euphorbiaceae & $*$ & $*$ & $*$ \\
\hline Flueggea virosa & $*$ & $*$ & $*$ \\
\hline Grewia sp (Tiliaceae) & $*$ & $*$ & \\
\hline Heliotropium sp (Boraginaceae) & & $*$ & \\
\hline $\begin{array}{r}\text { Hewitia scandens } \\
\text { (Convolvulaceae) }\end{array}$ & & $*$ & $*$ \\
\hline Hildegardia barteri (Sterculiaceae) & $*$ & $*$ & \\
\hline $\begin{array}{c}\text { Holarrhena floribunda } \\
\text { (Apocynaceae) }\end{array}$ & $*$ & $*$ & $*$ \\
\hline Hoslundia opposita (Lamiaceae) & $*$ & & \\
\hline $\begin{array}{c}\text { Hydrolea floridunda } \\
\text { (Hydrophyllaceae) }\end{array}$ & & & $*$ \\
\hline $\begin{array}{l}\text { Hymenocardia acida } \\
\text { (Hymenocardiaceae) }\end{array}$ & $*$ & $*$ & \\
\hline Hyphaene thebaica (Arecaceae) & $*$ & $*$ & \\
\hline Imperata cylindrica (Poaceae) & $*$ & $*$ & $*$ \\
\hline $\begin{array}{c}\text { Indigofera sp (Leguminosae- } \\
\text { Papilionoideae) }\end{array}$ & $*$ & $*$ & \\
\hline Ipomoea-type (Convolvulaceae) & $*$ & $*$ & $*$ \\
\hline
\end{tabular}




\begin{tabular}{|c|c|c|c|}
\hline List of the Species & $\begin{array}{c}\text { Sudanian } \\
\text { zone }\end{array}$ & Sudano-guinean zone & $\begin{array}{c}\text { Guinean } \\
\text { zone }\end{array}$ \\
\hline $\begin{array}{c}\text { Isoberlinia doka (Leguminosae- } \\
\text { Caesalpinoideae) }\end{array}$ & $*$ & $*$ & $*$ \\
\hline Jatropha sp (Euphorbiaceae) & $*$ & $*$ & $*$ \\
\hline Khaya senegalensis (Meliaceae) & * & $*$ & $*$ \\
\hline Kigelia africana (Bignoniaceae) & $*$ & $*$ & \\
\hline Lannea acida (Anarcadiaceae) & $*$ & $*$ & $*$ \\
\hline Lantana camara (Verbenaceae) & * & $*$ & $*$ \\
\hline $\begin{array}{c}\text { Lasiodiscus mildbraedii } \\
\text { (Rhamnaceae) }\end{array}$ & $*$ & & \\
\hline Leea guineensis (Leeaceae) & $*$ & & \\
\hline $\begin{array}{c}\text { Leucaena leucocephala } \\
\text { (Leguminosae-Mimosoideae) }\end{array}$ & $*$ & $*$ & \\
\hline Leucas type (Lamiaceae) & & $*$ & $*$ \\
\hline Loranthaceae & $*$ & $*$ & \\
\hline Ludwigia abyssinica (Onagraceae) & $*$ & $*$ & \\
\hline $\begin{array}{l}\text { Mallotus oppositifolius } \\
\text { (Euphorbiaceae) }\end{array}$ & $*$ & $*$ & * \\
\hline Malvaceae & $*$ & $*$ & * \\
\hline Mangifera indica (Anarcadiaceae) & * & * & * \\
\hline Meliaceae & $*$ & $*$ & $*$ \\
\hline $\begin{array}{l}\text { Melochia corcorifolia } \\
\text { (Sterculiaceae) }\end{array}$ & * & $*$ & \\
\hline $\begin{array}{l}\text { Microdesmis puberula } \\
\text { (Pandaceae) }\end{array}$ & $*$ & & $*$ \\
\hline Moraceae & $*$ & $*$ & $*$ \\
\hline $\begin{array}{c}\text { Mucuna sp (Leguminosae- } \\
\text { Papilionoideae) } 93\end{array}$ & & $*$ & \\
\hline Newbouldia laevis (Bignoniaceae) & $*$ & $*$ & $*$ \\
\hline Oryza-type (Poaceae) & & & $*$ \\
\hline Leguminosae-Papilionoideae & $*$ & $*$ & $*$ \\
\hline $\begin{array}{c}\text { Parinari curatellifolia } \\
\text { (Chrysobalanaceae) }\end{array}$ & $*$ & $*$ & * \\
\hline $\begin{array}{c}\text { Parkia biglobosa (Leguminosae- } \\
\text { Mimosoideae) }\end{array}$ & $*$ & $*$ & \\
\hline $\begin{array}{c}\text { Parkinsonia aculeata } \\
\text { (Leguminosae-Caesalpinoideae) }\end{array}$ & $*$ & * & \\
\hline Paullinia pinnata (Sapindaceae) & $*$ & $*$ & \\
\hline $\begin{array}{c}\text { Pentaclethra macrophylla } \\
\text { (Leguminosae-Mimosoideae) }\end{array}$ & $*$ & $*$ & * \\
\hline $\begin{array}{c}\text { Periscopsis laxiflora } \\
\text { (Leguminosae-Papilionoideae) }\end{array}$ & $*$ & $*$ & \\
\hline
\end{tabular}




\begin{tabular}{|c|c|c|c|}
\hline List of the Species & $\begin{array}{c}\text { Sudanian } \\
\text { zone }\end{array}$ & Sudano-guinean zone & $\begin{array}{c}\text { Guinean } \\
\text { zone }\end{array}$ \\
\hline $\begin{array}{l}\text { Phyllanthus amarus } \\
\text { (Euphorbiaceae) }\end{array}$ & & $*$ & $*$ \\
\hline $\begin{array}{c}\text { Piliostigma thonningii } \\
\text { (Leguminosae-caesalpinoideae) }\end{array}$ & * & $*$ & * \\
\hline Poaceae & $*$ & $*$ & $*$ \\
\hline $\begin{array}{c}\text { Prosopis africana (Leguminosae- } \\
\text { Mimosoideae) }\end{array}$ & $*$ & $*$ & $*$ \\
\hline Protea-type (Proteaceae) & & * & $*$ \\
\hline $\begin{array}{c}\text { Pterocarpus erinaceus } \\
\text { (Leguminosae-Papilionoideae) }\end{array}$ & * & $*$ & * \\
\hline $\begin{array}{c}\text { Pycnanthus angolensis } \\
\text { (Myristicaceae) }\end{array}$ & & * & * \\
\hline Rhynchelytrum repens (Poaceae) & $*$ & & \\
\hline $\begin{array}{c}\text { Rhyncosia sp (Leguminosae- } \\
\text { Papilionoideae) }\end{array}$ & $*$ & & \\
\hline Rubiaceae & * & * & * \\
\hline Sapindaceae & & * & * \\
\hline Sapotaceae/Meliaceae & $*$ & $*$ & $*$ \\
\hline $\begin{array}{l}\text { Sarcocephalus latifolus } \\
\text { (Rubiaceae) }\end{array}$ & * & * & \\
\hline $\begin{array}{c}\text { Securidaca longepedunculata } \\
\text { (Polygonaceae) }\end{array}$ & & $*$ & \\
\hline Sesamum indicum (Pedaliaceae) & $*$ & & \\
\hline Sida-type (Malvaceae) & * & * & * \\
\hline Spondias mombin (Anarcadiaceae) & * & * & $*$ \\
\hline Sterculia setigera (Sterculiaceae) & * & * & $*$ \\
\hline $\begin{array}{c}\text { Strophanthus preussii } \\
\text { (Apocynaceae) }\end{array}$ & $*$ & $*$ & \\
\hline Strychnos aculeata (Loganiaceae) & * & * & \\
\hline Syzygium guineense (Myrtaceae) & $*$ & $*$ & \\
\hline Tapinanthus type (Loranthaceae) & $*$ & & \\
\hline $\begin{array}{c}\text { Tephrosia-type (Leguminosae- } \\
\text { Papilionoideae) }\end{array}$ & * & $*$ & $*$ \\
\hline $\begin{array}{l}\text { Terminalia glaucescens } \\
\text { (Combretaceae) }\end{array}$ & * & * & \\
\hline Terminalia-type (Combretaceae) & * & * & * \\
\hline Trichilia emetica (Meliaceae) & $*$ & $*$ & \\
\hline Triumfetta pentandra (Tiliaceae) & $*$ & $*$ & \\
\hline $\begin{array}{l}\text { Tylophora sylvatica } \\
\text { (Asclepiadaceae) }\end{array}$ & * & $*$ & $*$ \\
\hline Utricularia tribracteata & $*$ & & $*$ \\
\hline
\end{tabular}




\begin{tabular}{|c|c|c|c|}
\hline List of the Species & $\begin{array}{l}\text { Sudanian } \\
\text { zone }\end{array}$ & Sudano-guinean zone & $\begin{array}{c}\text { Guinean } \\
\text { zone }\end{array}$ \\
\hline \multicolumn{4}{|l|}{ (Lentibulariaceae) } \\
\hline Verbenaceae (Verbenaceae) & $*$ & & $*$ \\
\hline Vernonia-type (Asteraceae) & & $*$ & $*$ \\
\hline $\begin{array}{c}\text { Vigna-type (Leguminosae- } \\
\text { Papilionoideae) }\end{array}$ & $*$ & $*$ & $*$ \\
\hline Virectaria multiflora (Rubiaceae) & & $*$ & $*$ \\
\hline Vitellaria paradoxa (Sapotaceae) & $*$ & & \\
\hline Zea mays L. (Poaceae) & & $*$ & $*$ \\
\hline Ziziphus-type (Rhamnaceae) & $*$ & & \\
\hline
\end{tabular}

\section{Relative density of the pollen grains}

According to these zones, the distinguished pollen groups are compile in Table 4 . Thus, Table 5 shows the absence of dominant pollens in all samples of honey analyzed (no pollen obtained a $\mathrm{Dr} \geq 45 \%$ ). The same observation was observed for accompanying or important pollen $(16 \leq \mathrm{Dr}$ $\leq 45 \%$ ) except in samples from the Guinean zone where Zea mays L. pollens are considered important pollen or accompanying pollen because they have had a relative density of 18.38 .

\section{Seasonal pollen richness}

The Figure 2 shows the variation of pollen according to seasons in the three zones. The sample curve of the Sudanian zone shows that the amount of pollen is very high with a peak at the level of the sample collected at Natitingou / Korimbéré $\left(\mathrm{SoS}_{7}\right)$ and a low level for the sample collected from Natitingou center $\left(\mathrm{SoS}_{8}\right)$. In the rainy season, the amount of pollen is decreasing. The sample collected from Bembèrèkè $\left(\mathrm{SoP}_{1}\right)$ contains 748 pollens, the largest amount in the rainy season.

In Sudano-guinean zone, the quantity of pollen were not homogeneouly distributed regarding the season (Figure 2). Thus, this might due to the short period of flowering of the species that coincides with the length of the seasons in the Sudano-guinean zone.

As for the Guinean zone, there was not neither big rises nor reductions on long periods of the quantity of pollens grains. It demonstrates the presence of the pollen grains in the honeys samples independently to the season in Guinean zone (Figure 2).

\section{Categorization of the honeys samples produced in rainy season}

The categorization of the honeys samples revealed three honey groups (Figure 3). The results of the hierarchical classification on the 
abundance data of the plants species pollens in the honeys showed a similarity between the honey samples coming from different climatic zones for all groups with the exception of the group $\mathrm{G}_{1}$ that is only constituted of sudanian honey (Figure 3 ). The $\mathrm{G}_{2}$ group is constituted mainly of Guinean and Sudano-guinean zones honey samples. The group $\mathrm{G}_{3}$ nearly gathers the honeys of the three climatic zones in number identical.

\section{Categorization of the honeys samples produced in dry season}

The pollen analysis of the honeys produced in dry season revealed three honeys groups (Figure 4 ). The first group $\left(\mathrm{G}_{1}\right)$ is constituted solely of the $\mathrm{SoS}_{10}$ honey of the sudanian zone, the second group $\left(\mathrm{G}_{2}\right)$ is also constituted of only sample of Guinean zone $\left(\mathrm{GuS}_{10}\right)$ and the third group $\left(\mathrm{G}_{3}\right)$ that are constituted of samples from the three zones.

Table 5: Pollens density class of the Sudanian, Sudano-Guinean and Guinean zones

\begin{tabular}{|c|c|c|c|}
\hline Density Class & Sudanian zone & $\begin{array}{c}\text { Sudano-guinean } \\
\text { zone }\end{array}$ & Guinean zone \\
\hline $\begin{array}{l}\text { Accompaniments } \\
\text { pollens or important } \\
16 \leq \mathrm{Dr} \leq 45 \%\end{array}$ & - & - & Zea mays L. (18.35) \\
\hline $\begin{array}{c}\text { Important Isolated } \\
\text { pollens } \\
3 \% \leq \text { Dr } \leq 16 \%\end{array}$ & $\begin{array}{c}\text { Terminalia } \\
\text { glaucescens }(10.01), \\
\text { Euphorbia type (4.54), } \\
\text { Detarium microcarpum } \\
\text { (7.40), Crossopterix } \\
\text { (7.51), Cassia } \\
\text { mimosoides }(3.26)\end{array}$ & $\begin{array}{c}\text { Alchornea } \\
\text { cordifolia }(3.22), \\
\text { Cochlospermum } \\
\text { planchonii (3.95), } \\
\text { Ipomoea type } \\
\text { (5.86), } \\
\text { Piliostigma } \\
\text { thonningii }(6.69), \\
\text { Pterocarpus } \\
\text { erinaceus }(9.04)\end{array}$ & $\begin{array}{c}\text { Terminalia type } \\
\text { (15.34), Diospyros } \\
\text { mespiliformis (3.57) }\end{array}$ \\
\hline $\begin{array}{l}\text { Isolated Pollen } \\
\text { Dr } \leq 3 \%\end{array}$ & $\begin{array}{c}\text { Adansonia digitata } \\
\text { (1.25), Berlinia } \\
\text { grandiflora }(1.01), \\
\text { Daniella oliveri }(2.01), \\
\text { Hymenocardia acida } \\
\text { (1.17), Parkia } \\
\text { biglobosa }(1.95), \\
\text { Piliostigma thonningii } \\
(2.40)\end{array}$ & $\begin{array}{c}\text { Zea mays } \mathrm{L} . \\
(1.24), \text { Trichilia } \\
\text { emetica }(1.80), \\
\text { Periscopsis } \\
\text { laxiflora }(2.13), \\
\text { Parkinsonia } \\
\text { aculeate }(2.08), \\
\text { Lannea acida } \\
(1.11) \\
\end{array}$ & $\begin{array}{c}\text { Sida type (2.46), } \\
\text { Entada type (1.68), } \\
\text { Prosopis africana } \\
\text { (1.95), Flueggea type } \\
\text { (2.18) }\end{array}$ \\
\hline
\end{tabular}




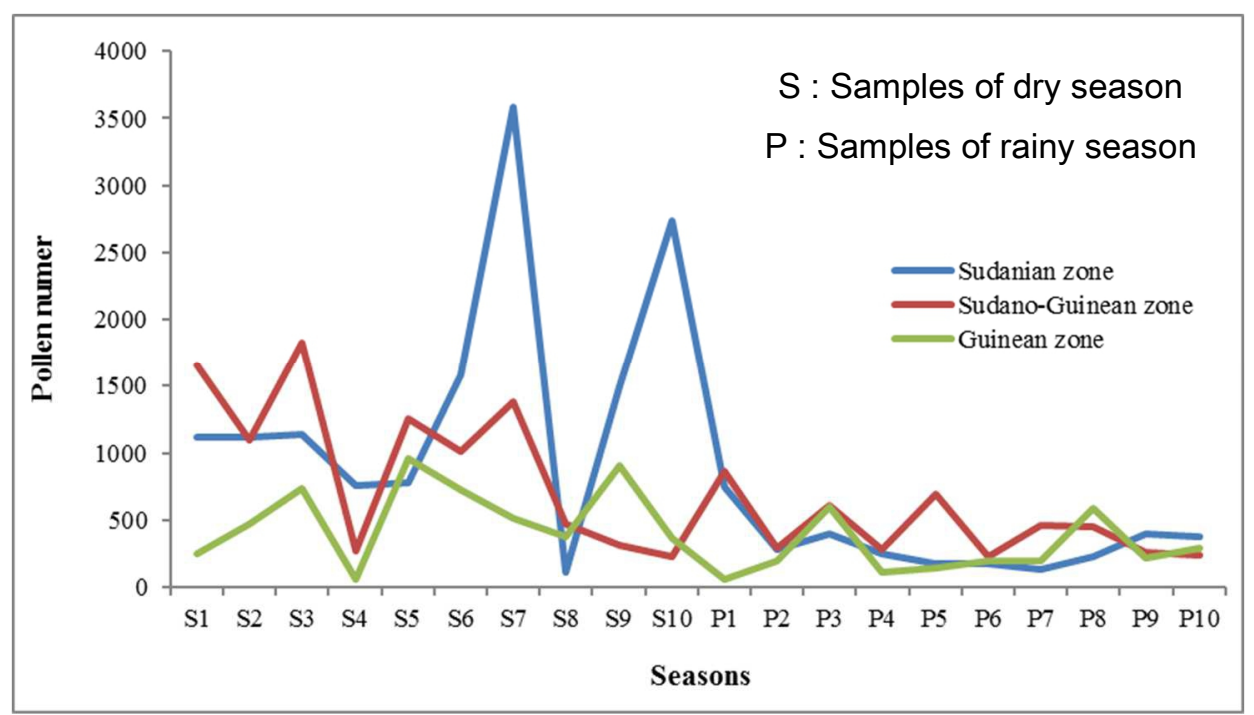

Figure 2: Variation of the pollens grains according to the seasons

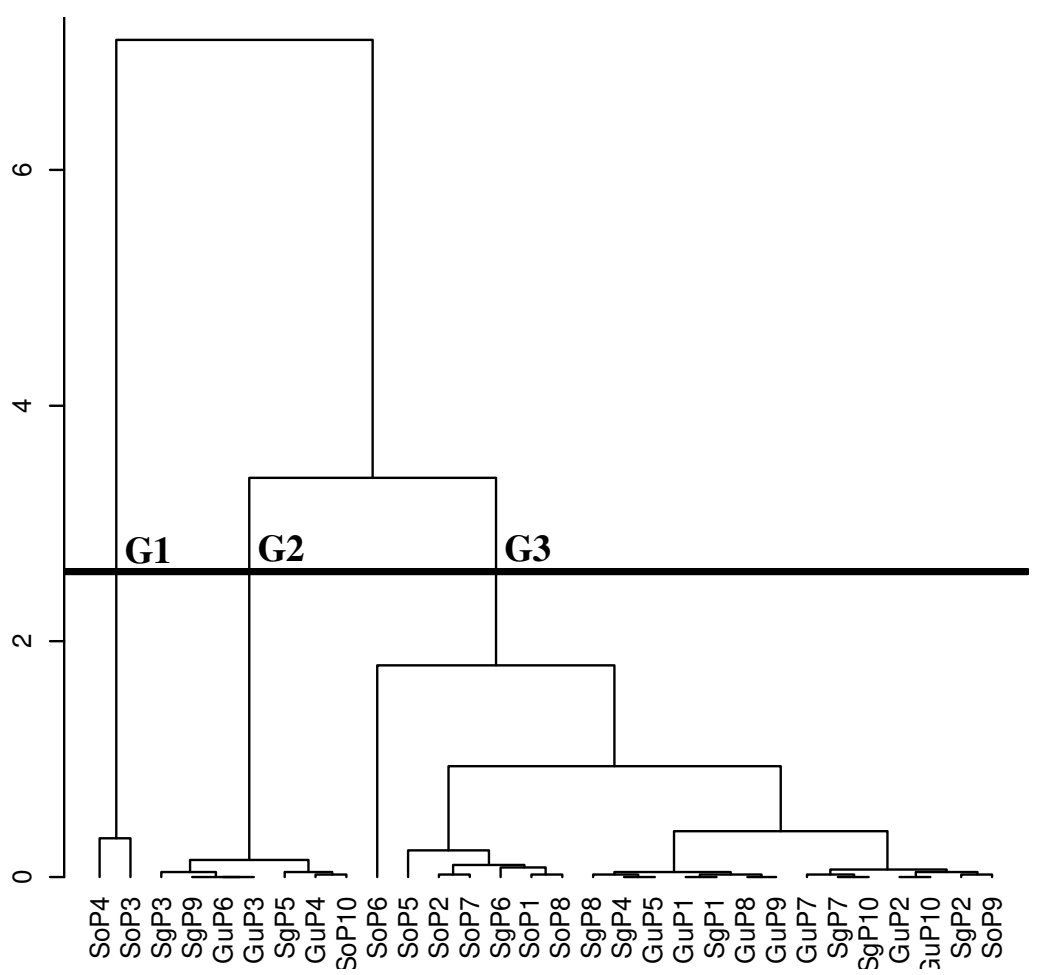

Face 3: Category of honeys according to the plants identifies in rainy season. 


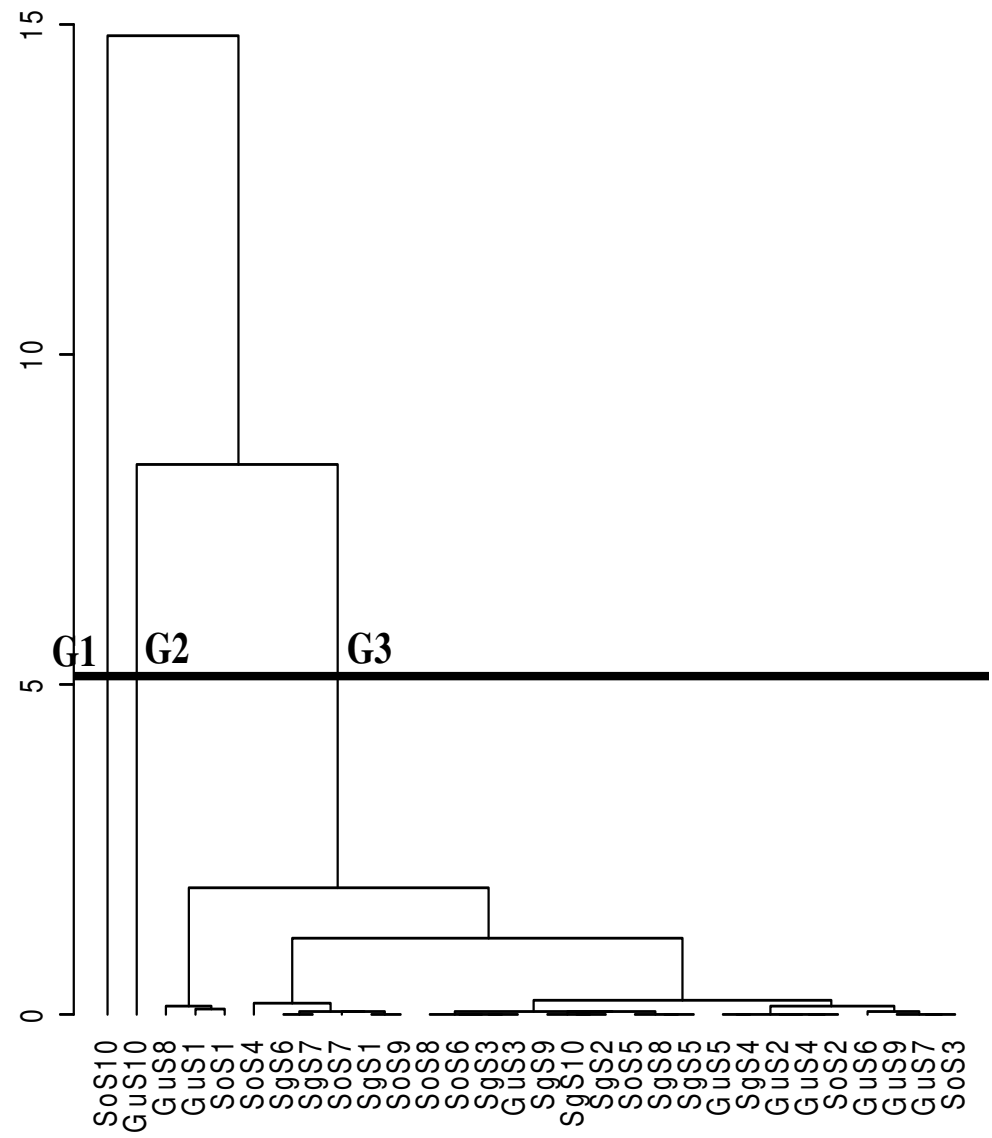

Figure 4. Category of honeys according to the plants identifies in dry season

\section{Discussion}

The pollen analysis of the 60 samples of honey collected in dry and rainy season permitted to identify 138 taxa belonging to 31 families, 20 kinds and 87 species. Those fund are similar to the 121 taxa identified in Southern Benin (Tossou et al., 2005). This specific diversity is very superior to the 14 species reported in Senegal by Diatta et al. (2017) during their contribution to the knowledge of honey plants. It is also superior to 34 species found by Mekious et al. (2015) in the region of Djelfa in Algeria and to 41 species obtained in Sudano-Guinean zone of Cameroon (Dongock et al., 2015), 43-45 species published after the pollen analysis and phytogeographical characterization of honeys in Benin (Tossou et al., 2011a, 2011b). To end, the number of honey plants species identified in our study is fairly superior to the 80 species observed in Central West of Benin (Yédomohan et al., (2009) and 87 species in the southern India (Ponnuchamy et al., 2014) previously reported. The difference of taxonomic diversity observes would be explained by several factors. First, this 
difference can be explained by the quantity of honeys samples analyzed, their period of collection and the floristic richness of the collection area. Also, the taxonomic variation can be justified by the fact that some of taxa where determined at the level kind and/or family.

The pollen sum varies from 58 to 2732 of pollens grains by sample. The biggest number of pollens (17091) has been gotten in the samples of the Sudanian zone, followed by 13884 (Sudano-guinean) and then 7960 pollens (Guinean zones). As for the wealth taxonomic by zone is very variable. It is 118 taxa in Sudanian zone, 112 taxa in Sudano-guinean zone and 89 taxa in Guinean zone. The taxonomic diversity is comparable with the data obtained by Yédomonhan et al. (2009) in Guinean zone (144 taxa) and in Sudanoguinean zone (108 taxa). The variation of the pollens quantity by geographical zone can be explained by the specific vegetation or plant met in every zone. The high number of taxa in Sudanian zone can be due to the fact that the diversity of species promote the research of nutriments by the bees in the two other zones.

The pollen richness of all honey samples shows that there are not dominant pollen. This fact, allows us to advance that in the honeys samples of the three zones are poly-floral. There is no mono-floral honeys in any of the samples collected from our study zones. Indeed, among the four groups of pollen determined by Feller-Desmaly and Parent (1989), only the groups of the important isolated pollens were observed in our analyzed honeys samples (Table 5). Thus, our results are similar to those reported in Northeast of Algeria (Chefrour et al., 2009) and Burkina Faso (Numbered et al., 2011). They are however not the same with the 60\% (mono-floral) and 40\% (multifloral) reported in the Sudano-guinean zone of Cameroon (Dongock et al., 2015). This pollen richness of the honeys is influenced by the floral morphology, phenology and floristically composition (Lobreau-Callen et Damblon, 1994). The absence of mono-floral honeys can be also explained by the absence of monocultures on a large scale, especially for the entomophiles pollination plants (Chefrours et al., 2007). It can however be noticed that among these isolated pollens, the pollens of Terminalia-Type and in general some Combretaceaes come in head in Sudanian zone and Sudano-guinean zone, while in Guinean zone these are rather the pollens of Zea mays L. (Poaceae). Elsewhere, some authors reported Elaeis guineensis to be the dominant species in Guinean zone (Koudegnan et al., 2010). The pollen spectra recovered in our study on the honeys of the three geographical zones is different from those returned in some works achieved on plains and mountains honeys of the Northern Algeria (Benaziza-Bouchema et al., 2010; Makhloufi et al., 2010; Nair et al., 2013).

The pollen richness of the samples is raised more in dry season than in rainy season in sudanian zone (14411 in dry season and 2680 in rainy 
season); in Sudano-guinean zone (9517 in dry season and 4367 in rainy seasons) and in Guinean zone (5351 in dry season and 2609 in rainy season). This situation can be explain by either by the absence of numerous species in bloom during the rains seasons or by the slowing of the foraging of bees by rains.

\section{Conclusion}

The pollen analysis of the honey samples collected from three phytogeographical zones of Benin indicates that honeys are constituted of the pollens of several taxa. All samples of honey are very rich in pollens. This pollen richness is especially more remarkable during the dry season than during the rainy season independently of the zones. Among identified taxa, some are founded either in the three zones or in two zones or in only one zone. It would be interesting to do some floristics inventories to better know the pollen analysis of those honey samples.

\section{Acknowledgements}

The authors thank the International Foundation of Science (IFS) which granted François Ezin AZONWADE (Research grant No. E/5720-1) and the government of Benin Republic for financial support.

\section{References:}

1. Agwu, C. O. C., \& Akambi, T. O. (1985). A palynological study of honey from four vegetation zones of Nigeria. Pollen et Spores 27 (34): 335-348

2. Agwu, O. C., Obuwekwe A. I., \& Iwu M. M. (1989). Pollen analytical and layer chromatographic examination of Nsukka (Nigeria) honey. Pollen et Spores 33:29-43.

3. Akoègninou A. (2004). Recherches botaniques et écologiques sur les forêts actuelles du Bénin. Thèses d'Etat, 326 p.

4. Akoègninou, A., Van der Burg W.J., \& Van Der Masen L. J. G. (2006). Flore analytique du Bénin. Wageningen: éditions Backhuys Publishers. Pays-Bas, 1034 p

5. Alvarez-Suarez, J.M., F. Giampieri \& M. Battino (2013). Miel comme une source d'antioxydants diététiques: Structures, bioavailability et évidences de protecteur effets contre maladies chroniques humaines. Curr. Med. Chem., 20: 621-638.

6. Benaziza-Bouchema, D., \& Schweitzer, P. (2010). Caractérisation des principaux miels des régions du Nord de l'Algérie. Cahier Agriculture. 19(6), 1-7.

7. Canini, A., DE Santis, L., Leonardi, D., Di Giustino, P., Abbale, F., Damesse, E., \& Cozzanir, R. (2005). Qualificazione dei mielie e 
piante nettarifere Del Camerun Occidentale. La Rivista di Scienza dell'Alimentazione, anno 34n, 4.

8. Chefrour, A., Battesti, M. J., Kaki, Y. A., \& Tahar, A. (2007). Melissopalynologic and physicochemical analysis of some north-east Algerian honeys, European. Journal. Sciences. Reseach. 18, 389-401

9. Chefrour, C., Draiaia, R., Tahar, A., Kaki, Y. A., Bennadja, S., \& Battesti, M. J. (2009). Physicochemical Characteristics and Pollen Spectrum of Some North East Algerian Honeys. African Journal of Food, Agriculture, Nutrition and Development, 9, 1276-1293.

10. Darrigol, J. L. (1996). Le miel pour votre santé. Propriétés thérapeutiques du miel, du pollen, de la gelée royale et de la propolis. Edition Dangles. 144 p.

11. Diatta, K., Battesti, M. J., Diatta, W., Fall Dior, A., Mbacke Dieng, S. I., Mbaye I. A., Goudiaby, A., Guisse, A., \& Bassene E. (2017). Contribution to the Knowledge of Melliferous Plants: Pollen Analysis of Supposed Honeys of Dialium guineensis (Fabaceae), by the Beekeepers of Ziguinchor (Senegal). American Journal of Plant Biology. Vol. 2, No. 1, pp. 35-42.

12. Dongock, N. D., \& Tchoumboue J. (2015). Palynological and Physicochemical Characterization of Honey in the Sudano-Guinean Zone of Cameroon. Food and Nutrition Sciences, 6, 1339-1350.

13. Dongock, N. D., Foko, J., Pinta, J. Y., Ngouo, L. V., Tchoumboue, J., \& Zango, P. (2004). Inventaire et identification des plantes mellifères de la zone soudano-guinéenne d'altitude de l'Ouest Cameroun. Tropicultura, 22(3), 139-145.

14. Erdtman, G. (1960). The acetolysis method. Svensk Botanisk Tidskrift, 54, 561-564

15. Erdtman, G. (1969). Pollen and spores preparations: the acetolysis method in handbook of Palynology, Munksgaard, Copenhagen, 213216.

16. Feás, X., Pires, J., Estevinho, M.L., Iglesias, A. \& De Araujo, J.P.P. (2010). Palynological and Physicochemical Data Characterisation of Honeys Produced in the Entre-Douro and Minho Region of Portugal. International Journal of Food Science and Technology, 45, 12551262.

17. Feller-Demasly, M. J., \& Patent, J. (1989). Analyse pollinique des miels de l'Ontario, Canada. Apidologie, 20, 127-138.

18. Koudegnan, C. M. (2010). Plantes méllifères de la zone guinéenne du Togo. Cas des zones écofloristiques IV et V. Mémoire. DEA, FDS, Univ. de Lomé, 78p.

19. Lobreau-Callen, D., \& Damblon F. (1994). Spectre pollinique des miels de l'abeille Apis mellifera L. (Hymenoptera, Apidae) et zone 
de végétation en Afrique occidentale et méditerranéenne. Grana: 245-253.

20. Louveaux, J., Maurizo, A., \& Vornwoh G., (1978). Methods of mellissopalynology. Bee World 59, 139-57.

21. Makhloufi, C., Kerkvliet, J. D., Ricciardelli d'Albore, G., Choukri, A., \& Samar, R. (2010). Characterization of Algerian honeys by palynological and physico-chemical methods. Apidologie, 41, 509521.

22. Mekious, S., Houmani, Z., Bruneau, E., Masseaux, C., Guillet, A., \& Hance, T. (2015). Caractérisation des miels produits dans la région steppique de Djelfa en Algérie, Biotechnologie, Agronomie, Société et Environnement. 2015 19(3), 221-231

23. Nair, S., Meddah, B., \& Aoues, A. (2013). Melissopalynological characterization of north Algerian honeys. Foods, 2, 83-89.

24. Njia, N. M. (1998). Caractéristiques socio-économique et technique de l'apiculture dans les Hauts Plateaux de l'Ouest Cameroun. Mémoire présenté en vue de l'obtention du diplôme d'Ingénieur Agronome. Université de Dschang, FASA, 75 p.

25. Ponnuchamy, R., Bonhomme, V., Prasad, S., Das, L., Patel, P., Gaucherel, C., Pragasam, A., \& Anupama, K. (2014). Honey Pollen: Using Melissopalynology to Understand Foraging Preferences of Bees in Tropical South India. Plosone 9(7):

26. Sinsin, B., Eyog Matig, O., Assogbadjo, A. E., Gaoué, O. G. \& Sinadouwirou, T. (2004). Dendrometric characteristics as indicators of pressure of Afzelia africana Sm. trees dynamics in different climatic zones of Benin. Biodiversity and Conservation 13, 15551570 .

27. Sowunmi, M. A. (1995). Pollen of Nigerian plants. II Woody species. Grana 34, 120-141.

28. Tchoumboue, J., Tchouamo, I.R., Pinta, I.J. \& Njia, M.N. (2001). Caractéristiques socio-économique et techniques de l'apiculture dans les Hauts plateaux de l'Ouest du Cameroun. Tropicultura, 19, 141146.

29. Tossou, G. M., Akoegninou, A., Yedomonhan, H., Batawila, K., \& Akpagana, K. (2005). Analyse pollinique des miels de la forêt classée de la Lama (Bénin) et son apport à la connaissance de la flore apicole. Journal de la Recherche Scientifique de l'Université de Lomé (Togo), Série A, 7, 83-92.

30. Tossou, M. G. (2002). Recherche palynologique sur la végétation holocène du Sud-Bénin (Afrique de l'Ouest). Thèse de doctorat unique, université de Lomé, 136p. 
31. Tossou, M. G., Yedomonhan, H., Azokpota, P., Akoegninou, A., Doubogan, P., \& Akpagana K. (2011a). Analyse pollinique et caractérisation phytogéographique des miels vendus à Cotonou (Bénin). Cahier d'Agriculture 20 : 500-508.

32. Tossou, M. G., Yédomonhan, H., Adomou, A. C., Demènou, B. B., Akoègninou, A., \& Traoré D. (2011b). Caractérisation pollinique des miels d'un élevage apicole dans l'arrondissement de manigri en zone soudano-guineenne au Bénin. Annale de la Botanique de l'Afrique de l'Ouest $78: 42-58$.

33. Ybert, J-P. (1979). Atlas de pollens de Côte d'Ivoire. Orstom, Initiations-documentations techniques, 40. Orstom. Paris, $40 \mathrm{p}$.

34. Yédomonhan, H. (2009). Plantes mellifères et potentialités de production de miel en zones guinéenne et soudano-guinéenne au Bénin. Thèse de doctorat, université d'Abomey-Calavi, 366p. 